\title{
A geodatabase of ancient spinning mills in Villa S. Giovanni and Cannitello (Calabria, Italy)
}

\author{
L. Battaglia \& G. Rudi \\ Department of Patrimony, Architecture, Urbanism (PAU), \\ University Mediterranea of Reggio Calabria, Italy
}

\begin{abstract}
Cataloging the cultural heritage, architectural artifacts, and material remains of ancient buildings and monuments is an important tool for preservation, restoration and comprehension of the history of architecture. With such knowledge it is possible to recreate the appearance of an environment, the evolution and transformations it has undergone through the ages, and to define the best practices for its preservation. In the 18th century, Calabria (Southern Italy) was one of the richest industrial territories in Italy, with a tremendous diversity in manufacturing: agricultural and food-based industries (in particular olive oil and citrus production); spinning mills; iron and steel mills and foundries. Then over recent years, as elsewhere, this region has suffered from the effects of deindustrialization and most of its industrial heritage is now demolished or left to ruin. The paper focuses on representative ancient spinning mills, realized during the 18th and 19th century in Villa S. Giovanni and Cannitello, a city famous in the past for silkworm breeding and for its numerous spinning mills. The research studies the places of production processes and the archaeological traces survived to urban changes, through the collection of archive documents. This paper also aims to demonstrate the potentiality of digital technologies - like the Geographic Information System (GIS) - in cataloguing and classification (instead of the use of traditional methods) and to present a GeoDatabase of the industrial heritage in Calabria. All the information resources regarding the Calabrian Industrial heritage (such as: ancient maps, old pictures, blueprints, sketches) and text data, have been pulled together and georeferenced on a GIS system. The use of digital and virtual technologies and the creation of the GeoDatabase, will help to investigate, enhance and even 'rescue'
\end{abstract}


these historic sites and monuments which are unique in the panorama of Italian industrial heritage.

Keywords: industrial heritage, spinning mills, Cannitello, Calabria, cataloging, geodatabase, GIS.

\section{An introduction to Calabria's industrial past}

It is a commonplace to think that northern Italy has always been the most industrialized area of the country, with highly developed economy and technological and infrastructural advancement.

In the period between the seventeenth century and the end of the nineteenth century, the production facilities in that area were on the same level of those in Northern Italy, in terms of value and technical performance and quality [1]. Moreover, before the 1861 Unification, Southern Italy (the "Kingdom of Two Sicilies") was the largest territorial state in Italy with the most industrialized cities, thanks to the protectionist policies of Southern Italy's Bourbon monarchs [2].

Calabria, one of the Two Sicilies Kingdom region, had a tremendous diversity in manufacturing: metal processing; chemicals; textiles and agricultural and food-based industries (like citrus fruit, olive oil, wine grapes and various vegetables).

The famous foundries of Ferdinandea and Mongiana; the industries of pipe "Vassas" in Aspromonte; the olive oil mills in Gioia Tauro; the watermills in the Gallico Valley, represent some of the various industries of the region.

Only some decades after Unification the lack of effective land reform, heavy taxes, and other economic measures imposed on the South, along with the removal of protectionist tariffs on agricultural goods imposed to boost northern industry, ruined the South's industries [3]. Thirty years later, however, as industrialization accelerated in the North, the Kingdom of Italy turned protectionist - too late to help South-based companies that were forced to close, but just in time to raise the prices of manufactured goods to southern consumers.

In addition, due to different factors including the 1908 earthquake, the crisis provoked by the Great War, and the lack of efficient road and railway connections, led to massive closure of industries in the South.

The testimony of this glorious past consists, today, mostly of ruins or buildings that have been converted for a new use.

\section{Historical evolution of silk industries in Villa S. Giovanni and Cannitello}

During the period between seventeenth century and nineteenth century Calabrian industries, despite the unfavorable conditions, have managed to carry out innovative activities comparable to the one achieved by the most developed countries.

Among these, the silk industry, developed from home worker activities of local families, made Calabria a nationally recognized industrial center. 
The silk trade has always played a fundamental role in the Calabrian economy.

The cultivation of the mulberry tree and the breeding of silkworms had already expanded enormously in Calabria during the sixteenth century (Calabrian fields enjoyed conditions that were especially favorable for the development of mulberry trees) and the Calabrian raw silk was so renowned that it was exported all over the Country, especially in Naples, Florence, Venice and Genoa where it was used for the manufacture of the popular Genoese velvets [4].

This favored the arrival of foreign merchant-entrepreneurs, who brought further expansion and new changes to methods of production.

The renovation took place especially in certain selected towns of Calabria, like Villa S. Giovanni and Cannitello (in the province of Reggio Calabria).

This area, in fact, thanks to its proximity to Messina and its port had unique characteristics associated with a greater opening up to the Mediterranean and to its commercial and technological exchanges. Due to this opening up, and due to its close ties with the Sicilian area of Messina, this strip of land would receive new technology, which would then renovate the silk throwing industry in a more rapid and radical manner compared to other Calabrian areas [5].

In 1847, Pietro Greco (Segretario Perpetuo della Società Economica di Calabria Ultra Prima), mentioned the "establishment of certain foreign industrialists in Villa S. Giovanni". Among them were: Thomas Hallam and his nephew Edward J. Eaton (from England) and Adriano Erba (from Milan).

According to the report of Pietro Greco, those entrepreneurs "took the factories on their own accounts and called upon people that could better understand the silk industry and the principles of sericulture science in order to provide the best management" [6].

The specialists hired to improve the production system of the spinning mills projected to build coal boilers to heat the water for the silk-throwing basins. But due to the raising fears, among the medical community and the population, of disease provoked by the soot emissions from coal combustion, the local authorities demanded to use charcoal instead of coal.

Until the early eighteenth century, then, the silk throwing process (known as "aspo grande" or "Calabrian style" [7]) was hand powered. Cocoons were put in a basin full of hot water and soap (the water was kept hot by a fire underneath the basin) and an operator whisked the cocoons with a small stick or a bunch until the natural gum with which the fiber is covered softens, and so allowed the thread to adhere to the stick, when the outer coating of the cocoon, being coarse and uneven, was stripped off and put aside as waste. After this coating was removed, the reeler found the end of the true or reelable thread, when four, five, or more of such ends were taken up and passed through a guide to make one thread. After the thread was reeled into skeins, it was cleaned; received a twist, to create a single strand, and was wound onto bobbins [8].

Only after the $1860 \mathrm{~s}$, due to the Industrial Revolution and the contribution provided by the use of the steam power in the manufacturing, Calabrian silk throwing was strongly influenced, expanded and technologically renovated. 
This improvement favored the construction of new spinning mills driven by steam engines that replaced or converted the old ones.

Starting from 1860, in Villa S. Giovanni and Cannitello, local mill owners followed the example of the foreigners and replaced the old hand powered spinning mills. Between 1848 and 1872 were built about 52 mills: 38 in Villa S. Giovanni and 14 in Cannitello, driven by both steam power and hand power [9].

\section{Recording of the major silk spinning mills in Villa S. Giovanni and Cannitello}

The conditions described above, made Villa S. Giovanni and Cannitello privileged areas for silk throwing, where it became possible to produce high quality silk at competitive prices. According to the relevant national bibliography and on-going researches, during the course of the $1860 \mathrm{~s}$, various foreign merchant-entrepreneurs established their own silk throwing mills and began their own production activities in these cities $[1,9]$.

In those years, many entrepreneurs renovated their old hand powered spinning mills, and other started to buy extensive plot of lands outside the city limits and to build new steam powered spinning mills [10]. For the first time, these mills used the steam boiler not only for heating the water for the silkthrowing basins, but also for turning the reels.

The most famous mills, due to their historical and technological significance, and also because they are now the only well-maintained, are the spinning mills: Erba, Cogliandro, Lamonica, Messina Brothers, Paolo Messina, and Lo Faro, all named after the respective families.

The first to be built were the mills belonged to the Messina family: Paolo Messina Spinning Mill in1860, and Messina Brothers Spinning Mill in 1862.

Paolo Messina Spinning Mill is three stories high and covered originally an area of 500 square meters. It consisted of one main building with a 15 meters tall chimney, a big central yard, and several smaller constructions (Fig. 1).

It has walls one and a half bricks' thick and a wooden gabled roof covered with tiles. Access to the upper floors is only possible via the internal staircases.

The lower two stories contained the room where the fresh cocoons were selected, piled and dried (essiccatoio) and another room with the boiler (locale caldaia) and the throwing machines (filatoio). The upper floor contained offices, and the factory employed 66 workers, mostly female.

Messina Brothers Spinning Mill was built two years later. It is three stories high and covers an area of 500 square meters. The two lowest floor have brick walls, while the upper floor has a wooden framework. From an external staircase that runs all over the facade and around the chimney, it is possible to reach the second floor that contained the boiler (with 36 basins) and the throwing machines. The adjacent building contained offices and the essiccatoio.

The other silk spinning mills: Lofaro Mill, built in 1864 (Fig. 2); Erba Mill, built in 1892 (Fig. 3); Cogliandro Mill, built in 1894 (Fig. 4); Lamonica built at the end of nineteenth century (Fig. 5), were realized with the same construction techniques [9]. 


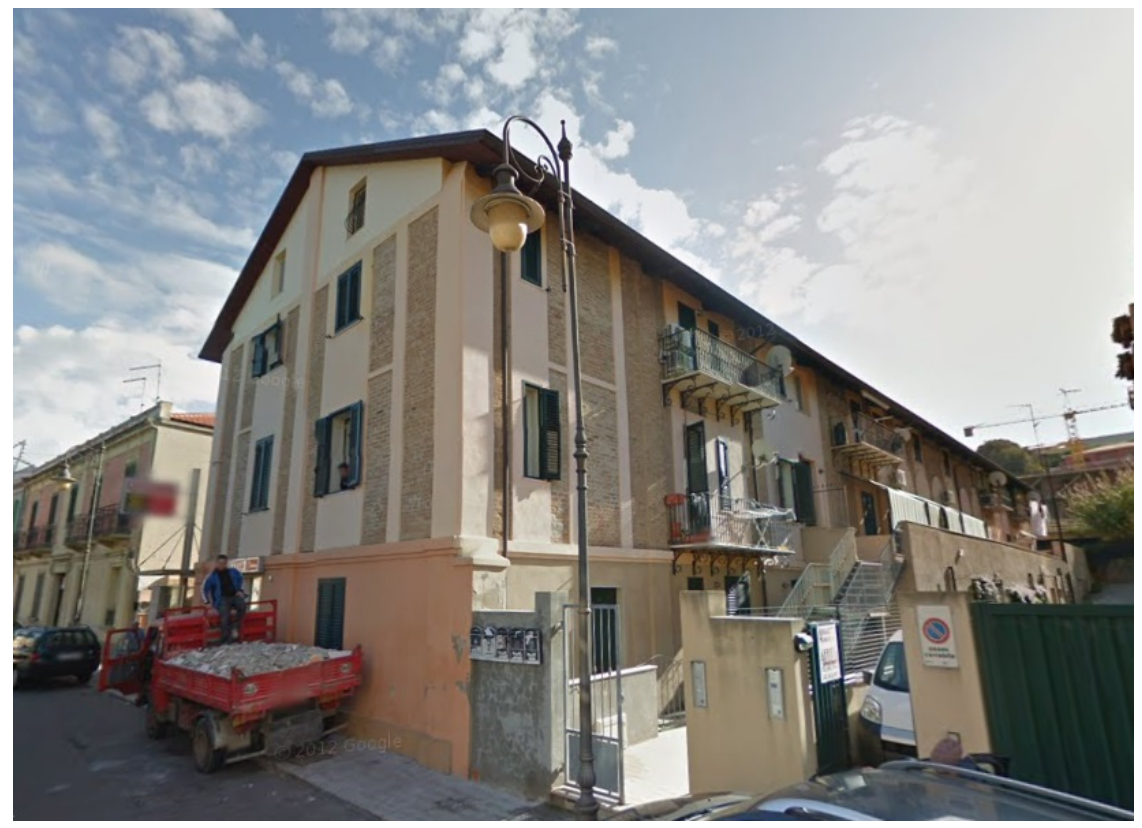

Figure 1: Paolo Messina Mill.

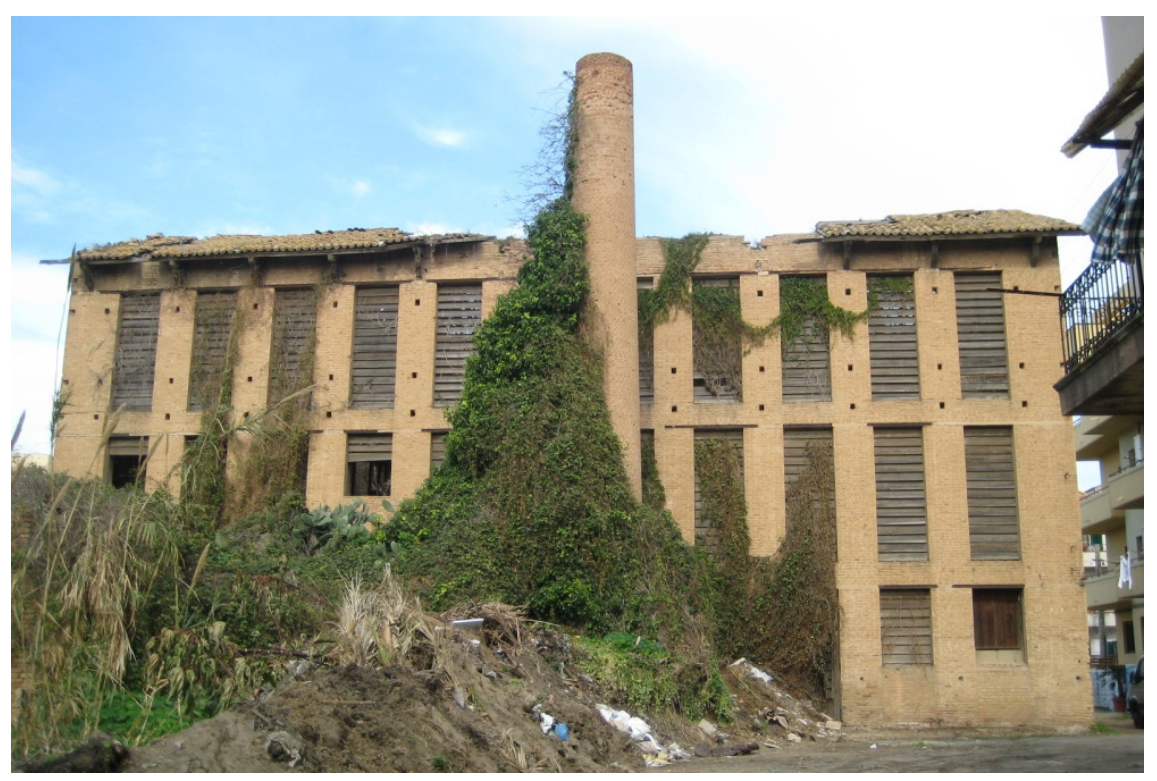

Figure 2: $\quad$ Lofaro Mill. 


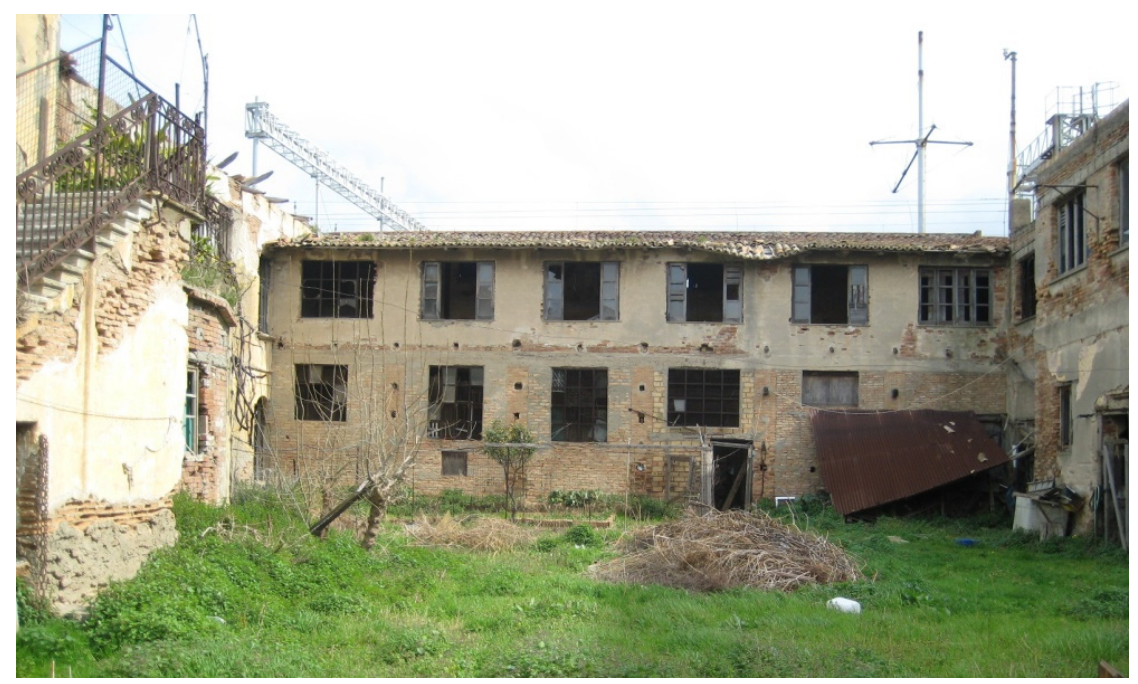

Figure 3: Erba Mill.

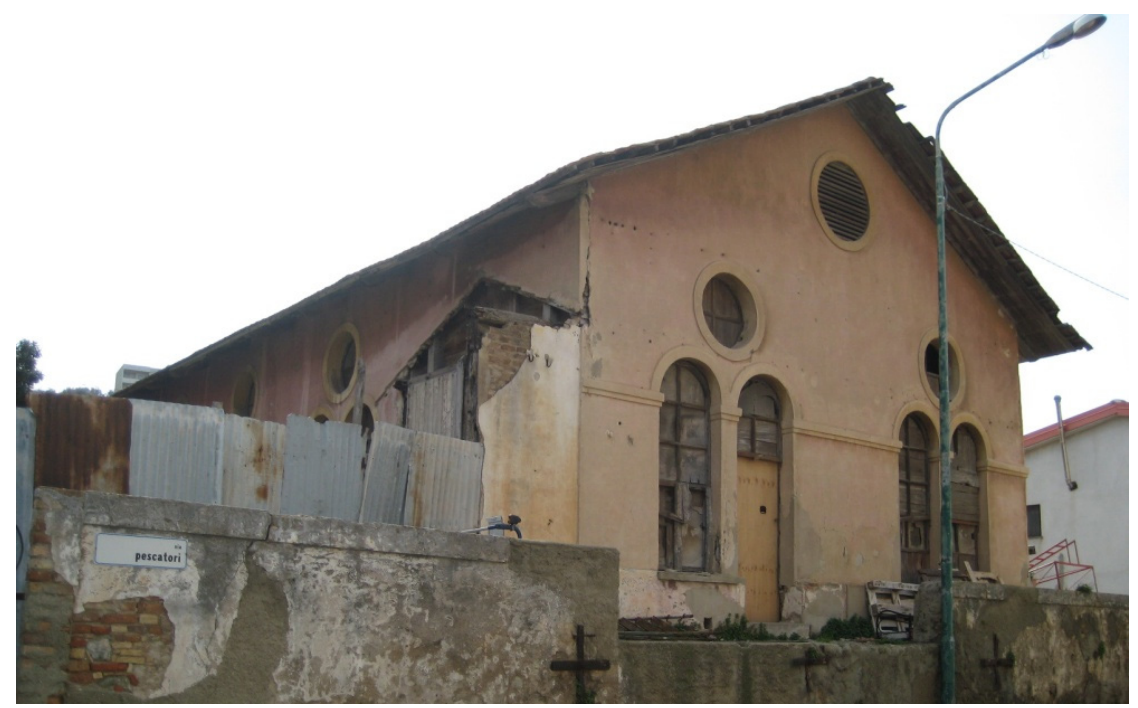

Figure 4: Cogliandro Mill.

Besides these industries managing to "survive" the 1908 earthquake, in the mid twentieth century, the crisis caused by the pébrine (a disease that made the silkworms unable to spin their thread), together with the rising price of raw silk and the strong competition of Northern Italy and foreign production, meant the end of sericulture in Calabria. All the mills that were slowly abandoned are now threatened by lack of maintenance and left in ruins, with the exception of 
Cogliandro Mills and Paolo Messina Mill, which have been converted for residential use.

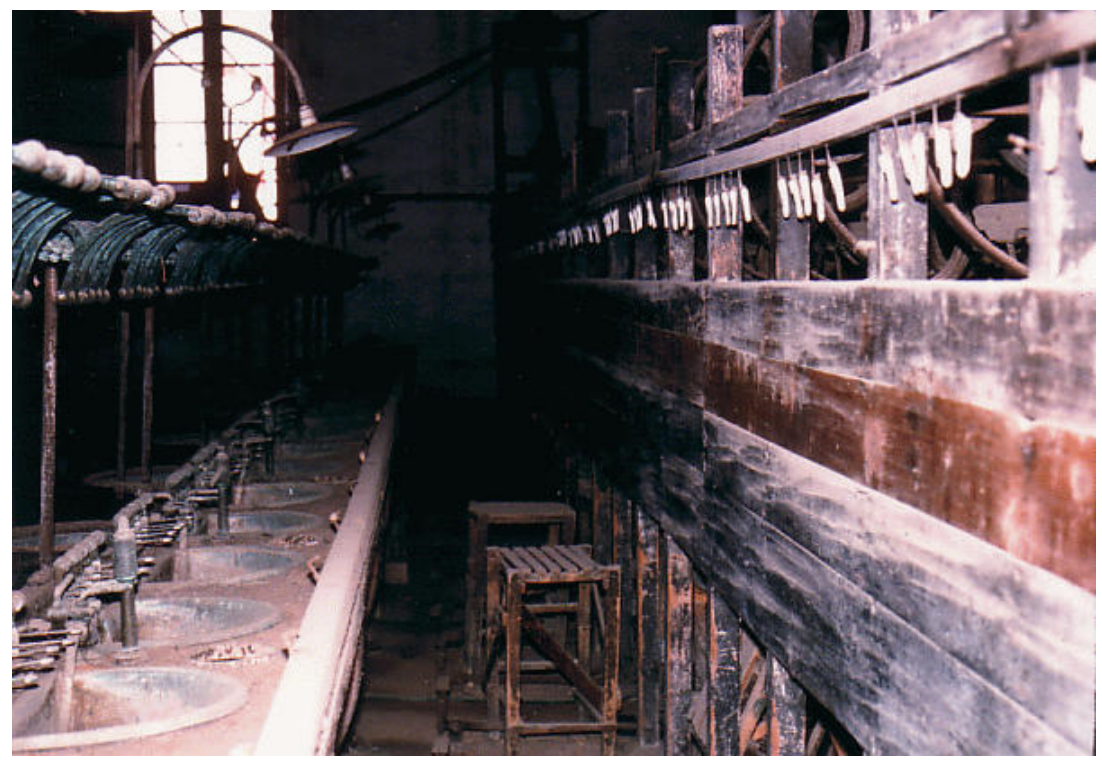

Figure 5: Silk-throwing basins of La Monica Mill.

\section{A geodatabase for urban and architectural conservation}

Our architectural heritage is a unique resource, an irreplaceable expression of the richness and diversity of a country and characterizes its past and the identity of its population.

During its lifetime, however, the architectural heritage is exposed to weather conditions and submitted to the flow of time that lead to its deterioration. In addition due people who lack awareness and consciousness of the significance of cultural heritage, due to government and public administrations neglect, and insufficient studies and researches, this heritage could be destined to disappear.

In order to prevent the destruction of this irreplaceable inheritance, it is important to define the most appropriate actions for its conservation and protection.

Conservation and preservation processes include the collection, evaluation, analysis, visualization and continuous monitoring of various data (such as maps, plans, drawings and photographs) collected from archives research and historic building investigation. These data groups, coming from different sources, necessitate the management of data in order to provide utilizable information.

With the purpose of getting a systematic and efficient data structure it was decided to organize a geodatabase through the software GIS (Geographical Information Systems), an important supporting tool developed to deal with complex and multifaceted geographical and spatial data. 
The working stages of the present study can be assembled into two groups: collection of the input information regarding Villa S. Giovanni and Cannitello spinning mills (and described in the previous paragraph), and the second phase of the "data structuring". In this phase, the collected data are transferred to the GIS by designing a database and defining a data model.

The first action consisted in collecting maps that have been georeferenced, in order to use them as a quantitative source for the study of urban historical development and as a base on which the information collected will be displayed.

The base maps used for this research are:

- a 1788 atlas map of the scale 1:114.000, published by the famous cartographer Rizzi Zannoni (1736-1814);

- a 1870 topographic map of the scale 1:50.000, published by the Royal Military Office;

- a 1954 topographic map of the scale 1:25.000, published by the Italian Military Geographic Institute;

- a 2014 satellite image, published by the Italian Military Geographic Institute.

These maps, that cover the municipal territory of Villa S. Giovanni and Cannitello and the entire Calabrian region, have been rectified to the UTM coordinate system (zone 33N European Datum WGS84) using control points at the crossings correlated with the same crossings from the satellite images.

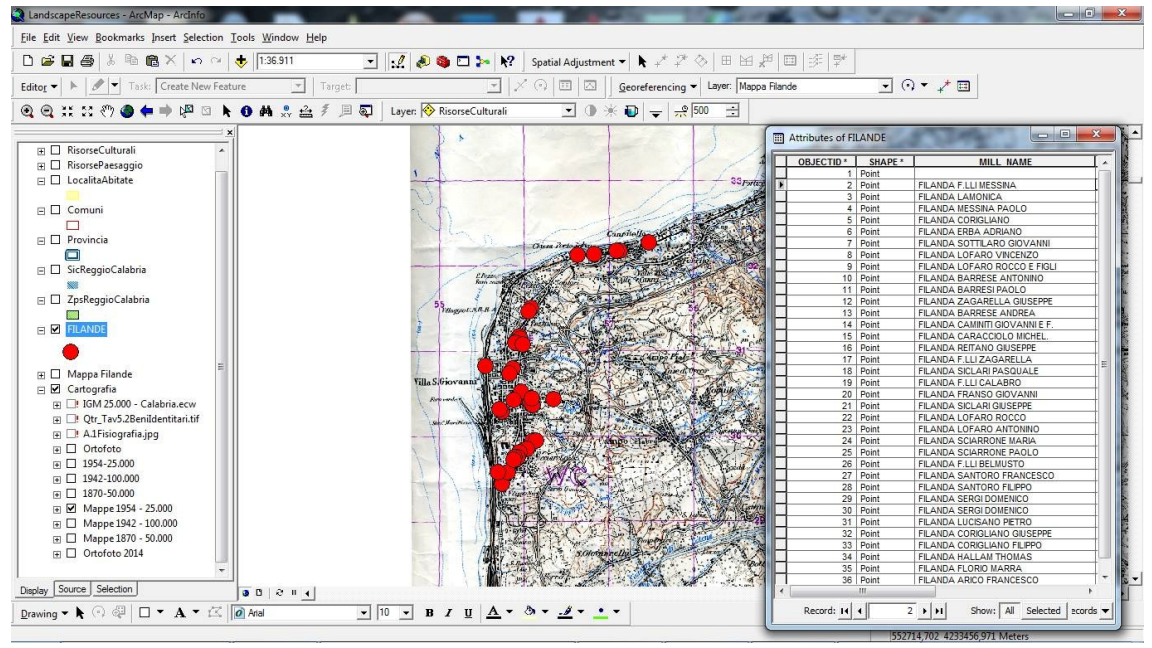

Figure 6: Attribute table of the silk spinning mills in Villa S. Giovanni and Cannitello. The base map is the 1954 topographic map of the scale $1: 25.000$.

The spinning mills have been individuated on these maps and satellite image and, next, was created an attribute table to contain descriptive information and raster source about the mills.

Each mill (feature class) is located on the maps with red icons and correlated to the database (the attribute table) as illustrated in Figure 6. 
Design of the database is one of the most important phases of a GIS base conservation methodology. At this phase, the necessary spatial data is decided and the database system is designed before entry the data.

The database include information such as the name of the mill, year of construction, status, actual use, physical data (number of stories, construction materials, etc.), technical data as in Figure 7 (construction typology, number of silk-throwing basins, boilers, drawings, etc.), raster data (ancient and modern photographs) - as shown in Figure 8.

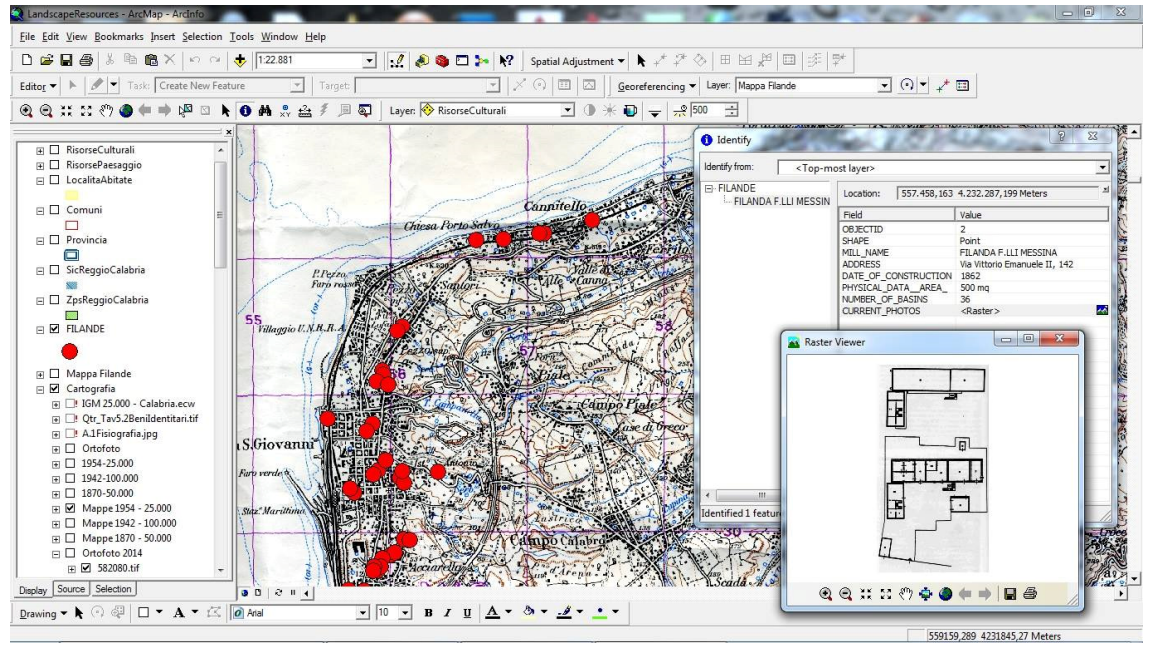

Figure 7: Data and drawing plan of Paolo Messina Mill.

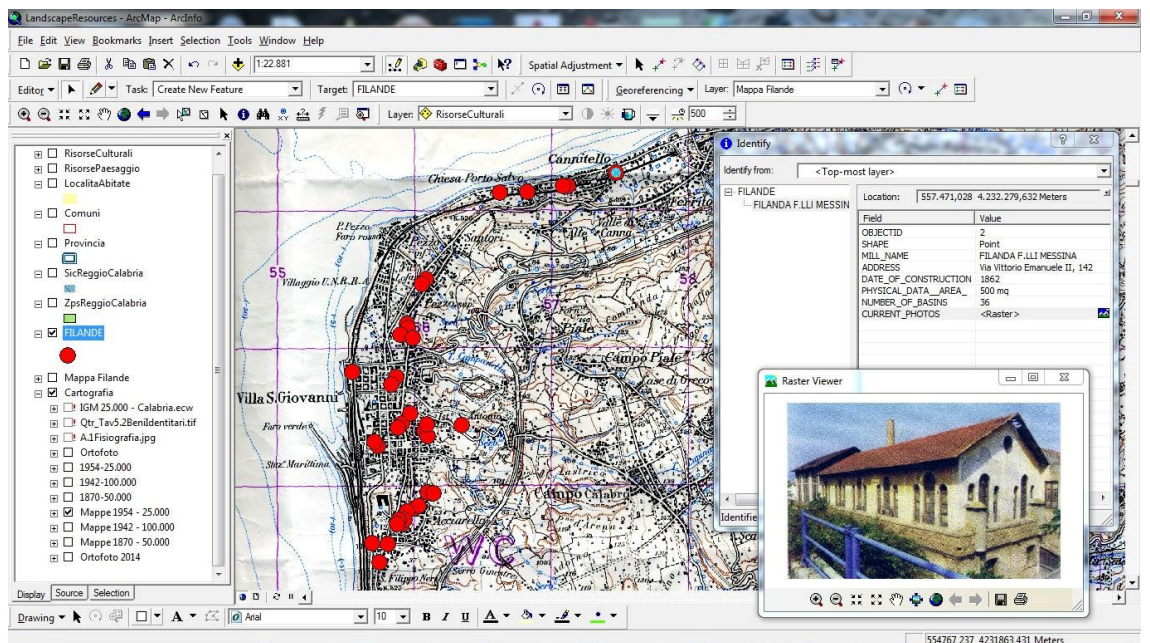

Figure 8: Data and photograph regarding Paolo Messina Mill. 
Due to the high number of raster drawings and pictures, the data for the areas that were investigated in detail are linked by hyperlinks.

These data have been acquired in the main libraries and archives located in the province of Reggio Calabria: the Reggio Calabria Municipal Library, the Mediterranean University Library, the State Archive in Reggio Calabria, and many private families archives.

\section{Outcomes}

The final result - a complete and functional geographic information system for industrial heritage, the spinning mills of Villa S. Giovanni and Cannitello allowed us to select and analyze data collected for the whole territory of the case studies and demonstrated that geographic information systems like GIS can be powerful instruments for designing conservation projects.

A new design-supporting GIS function is proposed in the research work, which will use the spatial database as a sketching platform for urban design proposals.

Conservation processes of historic buildings require the management of collected and evaluated data in order to maximize the quality of information gathered.

Data, in fact, represent the major component of conservation decision making process and the geographical information systems are the best data management tools for storing, organizing, analyzing, evaluating and monitoring this data.

Starting from the data entry to the system data is classified and categorized due to the data features.

The production of these kinds of display opportunities creates more efficient analysis and evaluations.

In particular, the geodatabase presented in this study allowed to analyze the enormous changes of the case studies: from the early nineteenth century some of the old buildings have been transformed, most of the spinning mills investigated in this paper have been converted or destroyed. Moreover, the overlapping between maps of different periods made possible to investigate the urban sprawl: in just one century the cities have tripled in size. In addition, different years' cartographies have been a great tool for finding exact year of construction of those buildings in which it was not possible to trace a year of construction for the lack of specific data archive.

The very potential of GIS technologies, however, resides in its designoriented uses that can be adapted to a large scale urban project.

In addition, the system provides the use of a database system that enables making queries between different data topics. These obtained information can also be visualized in different formats such as thematic maps, charts or graphics.

In conclusion, it is really important to catalog the largest number of buildings because, in case of loss or damage of the architectural heritage, the catalog itself could be seen as the only evidence of the cultural activities of past societies. 


\section{Acknowledgements}

L. Battaglia set up the research framework and authored sections 1, 2 and 3;

G. Rudi authored sections 4 and 5 .

\section{References}

[1] Matacena, G., Architettura del lavoro in Calabria tra i secoli XV e XIX, Edizioni Scientifiche Italiane: Napoli, 1945.

[2] Zamagni, V., Economic History of Italy 1860-1990, Oxford University Press: Oxford, 1993.

[3] Mack Smith, D., Modern Italy; A Political History. Michigan University Press: Ann Arbor, pp. 209-210, 1997.

[4] Sakellariou, E., Southern Italy in the Late Middle Ages: Demographic, Institutional and Economic Change in the Kingdom of Naples, c. 1440c. 1530, Brill Academic Publishers: Leiden, p. 387, 2012.

[5] Fusco, I., The spread of technology through commercial networks in the nineteenth century: foreign merchant-entrepreneurs and Calabrian sericulture amid changes and conflicts, The Historical Review/La Revue Historique Institute for Neohellenic Research, Volume VII, 2010.

[6] Greco, P., Relazione de' lavori della Società Economica di Calabria Ultra Prima compiuti nell'anno 1846. Letta nell'adunanza generale de' 30 maggio 1847. Atti della Società Economica della Prima Calabria Ulteriore: Reggio Calabria, p. 50, 1847.

[7] Grimaldi, D., Osservazioni economiche sopra la manifattura e commercio delle sete del Regno di Napoli alle sue finanze \& c., Giuseppe Maria Porcelli: Naples, pp. 28-29, 1780.

[8] Hollins, R., Silk throwing and waste silk spinning, Scott, Greenwood-Van Nostrand: London and New York, 1903.

[9] Iacona De Caridi, A., Le filande di Villa S. Giovanni. Quaderni PAU, 3, pp. 143-155, 1992.

[10] State Archive of Reggio Calabria, Prefettura, Inventario 14, envelope 35, fasc. 377 bis, 1853 . 